\title{
Pengaruh Corporate Governance terhadap Pengungkapan Sustainability Report pada Perusahaan di Indonesia
}

\author{
Ni'matul Hasanah, Dhaniel Syam, A.Waluya Jati \\ Program Studi Akuntansi Fakultas Ekonomi dan Bisnis \\ Universitas Muhammadiyah Malang \\ Jl. Raya Tlogomas No.246 Malang
}

\begin{abstract}
Abstrack
This study aims to examine the effect of Corporate Governance Effect on Sustainability Report Disclosure Report. This sample of 30 companies listed on the Indonesia Stock Exchange (IDX) in 2013 with purposive sampling technique. The data was analized with multiple linear regression. The result of the research stated that the average of attendance level of board of commissioners, board of directors and audit committee in the meeting did not affect the disclosure of sustainability report.
\end{abstract}

Keyword: Corporate Governance, Sustainability Report

\section{PENDAHULUAN}

Tujuan utama didirikannya perusahaan adalah untuk mencari keuntungan. Namun dalam mencapai tujuan tersebut seringkali perusahaan mengabaikan dampak sosial dan lingkungan yang dihasilkan dari limbah perusahaan. Sebagai contoh kasus PT.Newmont Nusa Tenggara (NNT) yang melakukan pencemaran di sungai Sekongkang dan sungai Torong Sejorong serta membuang limbah keteluk Senunu yang mengakibatkan penurunan kualitas lingkungan di perairan tersebut (www.jatam.org,2013). Hal ini menggambarkan bagaimana perusahaan hanya peduli terhadap peningkatan laba tanpa memperhatikan keadaan lingkungan sekitar. Dengan demikian maka adanya perusahaan tidak memberikan kontribusi bagi kemakmuran masyarakat dan lingkungannya tetapi justru mengalami penurunan kondisi sosial.

Secara umum dalam akuntansi konvensional (mainstream accounting) yang menjadi pusat perhatian perusahaan adalah stockholders, sedangkan pihak yang lain sering diabaikan. Semakin besarnya tuntutan perusahaan akhir-akhir ini, maka perusahaan diharapkan tidak hanya mementingkan kepentingan manajemen dan pemilik modal tetapi juga peduli terhadap karyawan, konsumen dan masyarakat. Perusahaan juga mempunyai tanggungjawab sosial dan lingkungan terhadap pihak-pihak di luar manajemen dan pemilik modal.

Tuntutan yang harus dilakukan perusahaan salah satunya adalah bagaimana tata kelola perusahaan (corporate governance) dapat berfungsi untuk mendorong terciptanya pasar yang efisien, transparan, dan konsisten dengan peraturan perundang-undangan yang berlandaskan pada beberapa prinsip dasa ryaitu pertanggungjawaban, transparansi, akuntabilitas, kesetaraan dan kewajaran (Rosadi,2011). Sebagai bentuk pertanggungjawaban dan transparansi pengelolaan perusahaan perlu adanya pemberian informasi yang lengkap mengenai kondisi perusahaan pada berbagai bidang.

Menurut Rachmandy (2012) bahwa corporate governance merupakan serangkaian mekanisme yang merefleksikan suatu struktur pengelolaan perusahaan

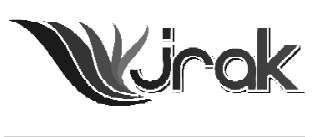

Jurnal Reviu Akuntansi dan Keuangan ISSN: 2088-0685 Vol.5 No. 1, April 2015 Pp 711-720 
Pengaruh

Corporate

Governance...

712

yang menetapkan distribusi hak dan tanggungjawab diantara berbagai partisipan di dalam perusahaan, termasuk para pemegang saham, dewan komisaris, dewan direksi, manajer, karyawan dan pihak-pihak berkepentingan (stakeholder) lainnya. Biasanya perusahaan hanya berpijak pada single bottom line, yaitu perusahaan hanya melaporkan kondisi keuangan perusahaan saja. Namun dengan munculnya teori triple bottom line maka perusahaan tidak hanya menyediakan informasi keuangan tetapi juga menyediakan informasi sosial dan lingkungan yang kemudian disebut dengan sustainability report (Ratnasari, 2011).

Sustainability report merupakan pelaporan yang dilakukan perusahaan secara sukarela, yang melaporkan sumbangsih perusahaan kepada masyarakat dilihat dari 3 aspek, yaitu ekonomi, sosial dan lingkungan. Sustainability report menggambarkan kepedulian perusahaan kepada masyarakat tentang aspek-aspek yang dilaporkannya dan juga menjembatani kebutuhan stakeholder terhadap informasi pengambilan keputusan (Pratiwi, 2013). Stakeholder adalah orang, kelompok, atau organisasi yang berada diluar kendali perusahaan yang terlibat dalam operasional perusahaan (Thomsett,2006). Perusahaan bertanggungjawab kepada stakeholder yaitu para pemegang saham, konsumen, para pegawai, para pemasok dan masyarakat. Sustainability terletak pada pertemuan antara tiga aspek, people-sosial; planet-environment; dan profit-economic. Maka menurut Elkington perusahaan harus bertanggung jawab atas dampak positif maupun negatif yang ditimbulkan terhadap aspek ekonomi, sosial dan lingkungan hidup (adhima, 2012).

Untuk mendukung adanya tanggungjawab perusahaan terhadap ketiga aspek tersebut maka pemerintah membuat kebijakan. Diantaranya adalah UU No.40 tahun 2007 tentang Perseroan Terbatas. Pasal 74 ayat 1 UU tersebut menyebutkan bahwa "Perseroan yang menjalankan kegiatan usahanya dibidang dan/ atau berkaitan dengan sumber daya alam wajib melaksanakan tanggung jawab sosial dan lingkungan (Ratnasari, 2011). Selain itu UU No.23 tahun 2007 tentang pengelolaan lingkungan hidup dan berdasarkan PP No.27 tahun 2007 pemerintah mengharuskan adanya AMDAL (Analisis mengenai dampak lingkungan) dari suatu proyek (Darmayanti, 2011). Menurut Reni dan Anggraini (2006) standar akuntansi keuangan belum mewajibkan perusahaan untuk mengungkapkan informasi mengenai tanggung jawab perusahaan terhadap lingkungan, akibatnya yang terjadi didalam praktik perusahaan hanya dengan sukarela mengungkapkannya.

Banyak penelitian berkaitan dengan pengungkapan sustainability report. Salah satunya penelitian yang dilakukan oleh Renidan Anggraini (2006) bahwa perusahaan akan mengungkapkan informasi tertentu jika ada aturan yang menghendakinya. Kemudian penelitian yang dilakukan oleh Pratiwi (2013) mengenai pengaruh corporate governance terhadap sustainability reporting menunjukkan hasil yang diteliti dengan menggunakan variabel kepemilikan institusional, dewan komisaris, proporsi dewan komisaris independen, dewan direksi dan komite audit tidak berpengaruh terhadap sustainability reporting. Sedangkan penelitian yang dilakukan oleh Nurkin (2009), Suryonodan Prastiwi (2011), dan Nugroho (2013) bahwa dewan komisaris, dewan direksi dan komite audit berpengaruh terhadap sustainability report.

Berdasarkan latar belakang dan perbedan hasil penelitian terdahulu maka peneliti tertarik untuk meneliti kembali terkait dengan pengaruh corporate governancce terhadap pengungkapan sustanbility report dengan tujuan untuk membuktikan secara empiris pengaruh corporate governance terhadap pengungkapan sustanbility report.

\section{PERUMUSAN HIPOTESIS}

Berdasarkan penelitian Nurkhin (2009) menjelaskan bahwa dewan komisaris berpengaruh terhadap pengungkapan tanggung jawab perusahaan, karena keberadaan dewan komisaris dapat memberikan kontrol dan monitoring bagi 
manajemen dalam operasional perusahaan, termasuk dalam pelaksanaan dan pengungkapan aktivitas tanggungjawab sosial. Namun hasil penelitian tersebut bertolak belakang dengan hasil penelitian yang dilakukan Pratiwi (2013) dan Fitri dan Subroto (2013), mengatakan bahwa dewan komisaris tidak terbukti mempengaruhi pengungkapan sustainability report.

$\mathrm{H}_{1}$ : Dewan komisaris berpengaruh terhadap pengungkapan sustainability report

Dalam pengertian yang sederhana, corporate governance dapat dilihat sebagai sekumpulan tatanan yang berlaku kedalam perusahaan yang selanjutnya menunjukkan hubungan- hubungan antara manajer dan pemegang saham. Sebagai pusat dari sistem ini adalah dewan direksi. Tanggungjawab utama dewan direksi adalah memastikan kelangsungan jangka panjang dari perusahaan dan untuk memberikan pengawasan dari manajemen. Dewan direksi juga mempunyai tanggungjawab dalam memastikan kepatuhan hukum dan peraturan perundangundangan, termasuk laporan yang bersifat sukarela yaitu menerbitkan sustainability report (Sutedi, 2012:182).

Berdasarkan penelitian Suryono dan Prastiwi (2011) menyebutkan bahwa dewan direksi berpengaruh terhadap praktik pengungkapan sustainability report. Penelitian ini didukung oleh penelitian yang dilakukan Widianto (2011) bahwa dewan direksi memberikan pengaruh positif terhadap praktik pengungkapan sustainability report.

$\mathrm{H}_{2}$ : Dewan direksi berpengaruh terhadap pengungkapan sustainability report

Berdasarkan international best practices Komite Audit mempunyai tugas dan tanggung jawab dalam bidang pelaporan keuangan (financial reporting), tata kelola perusahaan (corporate governance) dan pengawasan perusahaan (corporate control). Dalam bidang corporate governance, Komite Audit harus dapat memastikan bahwa perusahaan telah melaksanakan dan mematuhi semua peraturan hukum serta aturan lainnya yang berlaku serta memastikan perusahaan menjalankan kegiatan usahanya secara etis dan bermoral (Sutedi, 2012:162).

Berdasarkan penelitian Nugroho (2013) menyebutkan bahwa komite audit berpengaruh terhadap pengungkapan triple bottom line oleh perusahaan. Sedangkan menurut penelitian yang dilakukan Fitri dan Subroto (2013) ukuran komite audit, frekuensi komite audit dan kompetensi komite audit tidak berpengaruh terhadap pengungkapan corporate social responsibility.

$\mathrm{H}_{3}$ : Komite audit berpengaruh terhadap pengungkapan sustainability report

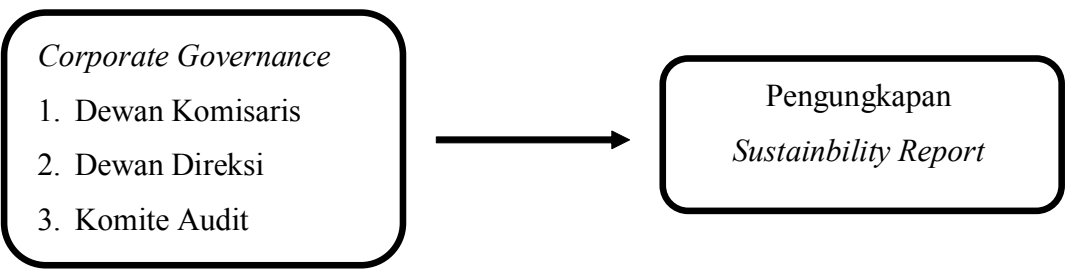

\section{METODE}

Jenis penelitian yang digunakan dalam penelitian ini adalah penelitian asosiatif. Data yang digunakan adalah data sekunder berupa Annual Report dan sustainability report perusahaan. Sumber data tersebut diperoleh dari website resmi Bursa Efek Indonesia dan website resmi masing-masing perusahaan sampel. Teknik pengambilan sampel adalah purposive sampling sehingga diperoleh sampel sebanyak 30 perusahaan. Teknik pengumpulan data dalam penelitian ini adalah dokumentasi.

Variabel independent dalam penelitian ini adalah dewan komisaris yang dimaksud adalah rata-rata tingkat kehadiran dalam rapat dewan komisaris dalam
Gambar 1 . Kerangka Pemikiran 
Pengaruh

Corporate

Governance...

714

perusahaan yang dilakukan oleh dewan komisaris dalam waktu satu tahun. Tingkat kehadiran rapat antara anggota dewan komisaris merefleksikan keefektifan dalam komunikasi dan koordinasi antara anggota dewan komisaris untuk mewujudkan good corporate governance (Ratnasari, 2011). Pelaksanaan corporate governance untuk dewan direksi diukur melalui rata-rata tingkat kehadiran rapat antara anggota dewan direksi yang telah terjadi selama periode satu tahun. Dalam penelitian ini menggunakan variabel komite audit yang ada di perusahaan dengan menghitung rata-rata tingkat kehadiran anggota komite audit dalam rapat selama satu periode (Ratnasari, 2011). Sedangkan variabel dependen dalam penelitian ini adalah sustainability report. Pengungkapan sustainability report dengan menggunakan indikator GRI 3.0 (Global Reporting Initiative). Indikator dalam GRI dibagi menjadi 3 yaitu: ekonomi, lingkungan hidup dan sosial. Total indikator yang ada mencapai 79 indikator yang terdiri dari 9 indikator ekonomi, 30 indikator lingkungan dan 40 indikator sosial.

\section{Analisis data dilakukan dengan tahapan sebagai berikut:}

1. Analisis statistik deskriptif

Analisis ini bertujuan untuk mendeskripsikan data yang diperoleh seperti data responden yang diteliti dan distribusi frekuensi masing-masing variable. Deskripsi yang diberikan dilihat dari nilai minimum, maksimum, rata-rata (mean), dan standar deviasi (Ghazali, 2011).

2. Uji Asumsi Klasik

a. Uji Normalitas

Uji normalitas dilakukan untuk mengetahui apakah populasi data berdistribusi normal atau tidak normal. salah satu metode ujinya adalah dengan menggunakan metode analisis grafik. Uji normalitas data dilakukan dengan uji Kolmogorov-Smirnov. Residual berdistribusi normal, bila tingkat signifikansinya lebih besar dari 0,05 .

b. Uji Multikolinearitas

Uji multikolinearitas digunakan untuk mengetahui ada atau tidaknya hubungan antar variabel independen. Model regresi yang baik adalah regresi yang tidak memiliki korelasi antar variabel independennya. Metode yang digunakan untuk mendeteksi gejala multikolinearitas, dengan menggunakan tolerance and Value Inflation Factor (VIF).

3. Uji Regresi Linear Berganda

Berdasarkan variabel independen dan dependen, maka dapat disusun persamaan sebagai berikut (Ghozali, 2011)

$\mathrm{Y}=\mathrm{a}+\mathrm{b} 1 \mathrm{x} 1+\mathrm{b} 2 \mathrm{x} 2+\mathrm{b} 3 \mathrm{x} 3+\mathrm{e}$

$$
\begin{array}{ll}
\text { Keterangan: } \\
\mathrm{Y} & =\text { Sustainability Report } \\
\mathrm{X} 1 & =\text { Dewan Komisaris } \\
\mathrm{X} 2 & =\text { Dewan Direksi } \\
\mathrm{X} 3 & =\text { Komite Audit } \\
\mathrm{A} & =\text { Konstanta } \\
\mathrm{b} 1 \mathrm{~b} 2 \mathrm{~b} 3 & =\text { Koefisien regresi }
\end{array}
$$

a. Uji koefisien Determinasi

Koefisien Determinasi $\left(\mathrm{R}^{2}\right)$ bertujuan untuk mengukur seberapa jauh kemampuan model dalam menerangkan variasi variabel dependen (Ghozali, 2011). Nilai koefisien determinasi adalah antara nol dan satu. Nilai $R^{2}$ yang kecil berarti kemampuan variabel-variabel independen dalam menjelaskan variasi variabel dependen amat terbatas. 
b. Uji Signifikansi Simultan (Uji Statistik F)

Uji signifikansi simultan (uji statistik F) bertujuan untuk mengukur apakah semua variabel independen yang dimasukkan dalam model mempunyai pengaruh secara bersama-sama terhadap variabel dependen (Ghozali, 2006). Pengujian secara simultan ini dilakukan dengan cara membandingkan antara tingkat signifikansi $\mathrm{F}$ dari hasil pengujian dengan nilai signifikansi yang digunakan dalam penelitian ini.

c. Uji Signifikansi Parameter Individual/Parsial (Uji Statistik t)

Uji signifikansi parameter individual (uji statistik t) bertujuan untuk mengukur seberapa jauh pengaruh satu variabel independen secara individual dalam menerangkan variasi variabel dependen (Ghozali, 2011). Pengujian secara parsial ini dilakukan dengan cara membandingkan antara tingkat signifikansi t dari hasil pengujian dengan nilai signifikansi yang digunakan dalam penelitian ini.

\section{HASIL DAN PEMBAHASAN}

\section{Statistik Deskriptif}

\begin{tabular}{llllll}
\hline & N & Minimum & Maximum & Mean & Std.Deviation \\
\hline Sustainability & 30 & 11,00 & 100,00 & 52,4667 & 26,36447 \\
Komisaris & 30 & 47,00 & 100,00 & 85,2000 & 14,03297 \\
Direksi Komite & 30 & & 100,00 & 88,5000 & 8,60132 \\
ValidN & 30 & 68,00 & 100,00 & 85,4333 & 15,28732 \\
(listwise) & 30 & 45,00 & & & \\
\hline
\end{tabular}

Tabel 1.

Hasil Pengujian Statistik Deskriptif

Sumber: Data diolah, 2015

Dari data sustainability report menunjukkan nilai minimum sebesar 11,00 pada PT. Patra Jasa dan untuk data maksimum sebesar 100,00 pada PT.Inti Agro Resources dan PT.Kaltim Prima Coal. Dengan nilai mean sebesar 52,4667 dan standar deviasi 26,36447 menggambarkan standar deviasi yang sangat besar (sebesar 50\% dari mean). Hal ini menunjukkan adanya kesenjangan yang besar dari sustainability report minimum dan maksimum.

Untuk variabel dewan komisaris memiliki nilai minimum 47,00 pada PT. Pertamina dan nilai maksimum 100,00 pada beberapa perusahaan yaitu PT. Asabri (Persero), Bank Syariah Mandiri, Bank OCBC NISP, PT.Indocement Tunggal Prakarsa Tbk, PT.Indo Tambang raya Megah Tbk, PT. Total Bangun Persada Tbk, PT. LEN Industri (Persero) dan PT. Patra Jasa (Persero).Dari 30 sampel yang digunakan dalam penelitian tingkat kehadiran komisaris memiliki nilai mean 85,2000 dengan standar deviasi 14,03297 yang menjelaskan bahwa tingkat kesenjangan sebesar $16 \%$ dari rata-rata tingkat kehadiran dewan komisaris minimum dan maksimum.

Variabel dewan direksi memiliki nilai minimum 68,00 pada Bank Pembangunan Daerah Jawa Barat dan Banten dan nilai maksimum 100,00 pada PT. Indocement Tunggal Prakarsa Tbk, PT. Inti Agro Resources Tbk, PT. Indo Tambang raya Megah PT. Semen Indonesia (Persero) Tbk, PT.LEN Industri (Persero) dan PT.Patra Jasa (Persero). Dari seluruh sampel yang digunakan dalam penelitian ini, rata-rata tingkat kehadiran dalam rapat memiliki nilai mean sebesar 88,5000 dengan standart deviasi 8,60132 yang menjelaskan nilai kesenjangan sebesar $9,72 \%$.

Variabel komite audit memiliki nilai minimum 45,00 pada Bank Tabungan Negara, sedangkan nilai maksimum 100,00 terdapat pada PT. Asabri (Persero), 
Pengaruh

Corporate

Governance...

716
PT. Astra Internasional Tbk, PT.Indocement Tunggal Prakarsa Tbk, PT.Inti Agro Resources Tbk, PT. Jaminan Sosial Tenaga Kerja (Persero), PT. Jasa Raharja (Persero), PT.United Tractors Tbk, PT.LEN Industri (Persero) dan PT.Patra Jasa (Persero). Nilai mean pada variabel komite audit sebesar 85,4333 dan standar deviasinya sebesar 15,28732 . Hal ini menunjukkan tingkat kesenjangan sebesar $18 \%$.

\section{Asumsi Klasik}

a. Uji Normalitas
Gambar 2 Uji Normalitas Data
Tabel 2. Hasil Uji
Normal P.P Plot of Regression Standardized Residual

Dependent Variable: Sustainability

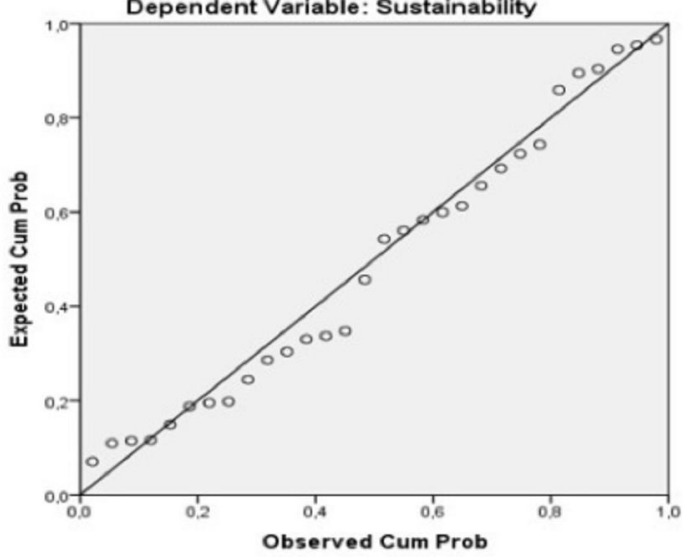

Dari gambar diatas dapat disimpulkan bahwa terlihat titik- titik menyebar disekitar garis diagonal dan mengikuti arah garis. Dengan demikian maka model regresi memenuhi asumsi normalitas. Sehingga model regresi layak dipakai untuk pengungkapan sustainability report berdasarkan variabel independennya.

b. Uji Multikolinearitas

\begin{tabular}{lcc}
\hline \multirow{2}{*}{ Model } & \multicolumn{2}{c}{ CollinearityStatistics } \\
\cline { 2 - 3 } & Tolerance & VIF \\
\hline Komisaris &, 632 & 1,582 \\
direksi &, 711 & 1,406 \\
audit &, 664 & 1,506
\end{tabular}

Sumber:Data diolah, 2015

Pada tabel di atas terlihat bahwa untuk ketiga variabel independen mempunyai angka VIF kurang dari 10 yaitu 1,582, 1,406 dan 1,506. Sedangkan angka tolerance lebih dari 0,10 yaitu 0,632, 0,711 dan 0,664. Dari hasil tersebut dapat disimpulkan bahwa pada model regresi tidak terjadi multikolinieritas atau hubungan antar variabel independen.

\section{Analisis Regresi Linear Berganda}

a. Uji Koefisien Determinasi (R2)

Pengujian koefisien determinasi bertujuan untuk mengukur seberapa jauh kemampuan variabel dependen. Nilai yang mendekati satu variabel berarti variabel-variabel independen memberikan hampir semua informasi yang dibutuhkan untuk memprediksi variabel dependen. 


\begin{tabular}{cccccc}
\hline Model & R & R Square & $\begin{array}{c}\text { AdjustedR } \\
\text { Square }\end{array}$ & $\begin{array}{c}\text { Std.Errorof } \\
\text { theEstimate }\end{array}$ & $\begin{array}{c}\text { Durbin- } \\
\text { Watson }\end{array}$ \\
\hline 1 &, $242^{\mathrm{a}}$ &, 058 &,- 050 & 27,01885 & 2,357 \\
\hline
\end{tabular}

Sumber:Data diolah, 2015

Dari tabel diatas dapat diketahui bahwa $\mathrm{R}$ square atau koefisien determinasinya 0,058 (berasal dari $0,242 \times 0,242$ ). Hal ini berarti variabel independen dalam penelitian ini menerangkan variabel dependennya sebesar $5,8 \%$ dan sisanya dijelaskan oleh faktor-faktor lain.

b. Uji Simultan (Uji-F)

\begin{tabular}{lccccc}
\hline \multicolumn{1}{c}{ Model } & $\begin{array}{c}\text { Sum of } \\
\text { Squares }\end{array}$ & df & $\begin{array}{c}\text { Mean } \\
\text { Square }\end{array}$ & F & Sig. \\
\hline $\begin{array}{l}\text { Regression1 Residual } \\
\text { Total }\end{array}$ & 1176,995 & 3 & 392,332 &, 537 &, $661^{\text {b }}$ \\
& 18980,472 & 26 & 730,018 & & \\
& 20157,467 & 29 & & &
\end{tabular}

Tabel 4.

Hasil Uji-F

Sumber:Data diolah, 2015

Dari uji ANOVA dapat dilihat bahwa hasil uji-F yang telah dilakukan mempunyai nilai signifikansi atau probabilitasnya 0,661 . Nilai probabilitas tersebut lebih besar dari 0,05 sehingga H0 diterima. Dengan demikian dapat disimpulkan bahwa secara simultan atau bersama-sama seluruh variabel independen tidak berpengaruh terhadap sustainability report.

c. Uji Parsial (Uji-t)

\begin{tabular}{lrrrrr}
\hline & \multicolumn{2}{c}{$\begin{array}{c}\text { UnstandardizedCoef } \\
\text { ficients }\end{array}$} & $\begin{array}{c}\text { Standardized } \\
\text { Coefficients }\end{array}$ & T & Sig. \\
\cline { 2 - 4 } & \multicolumn{1}{c}{ B } & Std.Error & Beta & & \\
\hline (Constant) & 68.012 & 52.296 & & 1.301 & .205 \\
Komisaris &,- 349 &, 450 &,- 186 &,- 775 &, 445 \\
Direksi &,- 299 &, 692 &,- 098 &,- 432 &, 669 \\
Komite &, 476 &, 403 &, 276 & 1,181 &, 248 \\
\hline
\end{tabular}

Tabel 5.

Hasil Uji-t

Dari tabel diatas dapat diketahui hasil bahwa signifikansi untuk variabel dewan komisaris dengan proksi rata-rata tingkat kehadiran anggota dalam rapat sebesar 0,445. Hal ini menunjukkan bahwa probabilitas dewan komisaris lebih besar dari 0,05 sehingga dewan komisaris ditolak dan H0 diterima. Dengan demikian dapat disimpulkan bahwa dewan komisaris tidak berpengaruh terhadap sustainability report.

Pada variabel dewan direksi yang diproksi dengan rata-rata tingkat kehadiran anggota dalam rapat diketahui nilai signifikansinya lebih besar dari 0,05 yakni 0,669. Dengan demikian hipotesis untuk dewan direksi ditolak dan $\mathrm{H} 0$ diterima. Sehingga dapat disimpulkan bahwa dewan direksi tidak berpengaruh terhadap sustainability report.

Pada variabel komite audit yang diproksi dengan rata-rata tingkat kehadiran anggota dalam rapat diketahui bahwa nilai signifikansinya lebih besar dari 0,05 yakni 0,248. Dengan demikian hipotesis untuk komite audit ditolak dan $\mathrm{H0}$ diterima. Sehingga dapat disimpulkan bahwa komite audit tidak berpengaruh terhadap sustainability report. 
Pengaruh

Corporate

Governance...

718
Pengaruh Dewan Komisaris, Dewan Direksi, dan Komite Audit terhadap Pengungkapan Sustainability Report

Berdasarkan hasil Uji-t diatas maka semua variabel indenpenden yang terdiri dari dewan komisaris, dewan direksi dan komite audit tidak berpengaruh terhadap pengungkapan sustainability report. Hasil penelitian ini dengan menggunakan rata-rata tingkat kehadiran anggota dewan komisaris, dewan direksi dan komite audit dalam rapat menunjukkan ketidak sesuaian antara hasil dan hipotesis. Hasil penelitian ini mendukung penelitian yang telah dilakukan oleh Fitri dan Subroto (2013) dan Pratiw i(2013) yang menyatakan bahwa dewan komisaris, dewan direksi dan komite audit tidak berpengaruh terhadap pengungkapan sustainability report. Namun hasil ini tidak konsisten dengan penelitian yang dilakukan oleh Saridan Marsono (2013), Suryono dan Prastiwi (2011) dan Widianto (2011) yang menyatakan bahwa dewan komisaris, dewan direksi dan komite audit berpengaruh terhadap pengungkapan sustainability report.

Tujuan dari sustainability seharusnya adalah selalu mendorong pelakuan yang bertanggung jawab lebih daripada hanya mencegah perbuatanyang salah (Sutedi, 2011: 12). Bentuk tanggungjawab ini bisa dicerminkan dengan praktik corporate governance dalam sebuah perusahaan. Salah satu praktiknya adalah dengan mengadakan pertemuan berkala secara teratur antar organ perusahaan. Dari teori tersebut peneliti menyimpulkan bahwa semakin besa rrata-rata tingkat kehadiran rapat yang dilakukan dewan komisaris, dewan direksi dan komite audit seharusnya mempengaruhi pengungkapan sustainability report. Akan tetapi hasil penelitian ini bertolak belakang dengan teori tersebut. Hal ini disebabkan karena hasil pembahasan dalam rapa thanya membahas kinerja perusahaan yang lebih dititik beratkan pada laporan yang bersifat wajib. Berdasarkan BAPEPAM No.38/ PM/1996 (dalam Putri, 2014) terdapat dua jenis laporan tahunan yaitu laporan wajib berupa laporan keuangan dan laporan bersifat suka rela seperti sustainability report. sehingga pembahasan kinerja terhadap pengungkapan sustainability report menjadi hal yang tidak diutamakan jika dibandingkan dengan pengungkapan laporan keuangan.

\section{SIMPULAN}

Berdasarkan hasil analisis dan pembahasan yang telah dilaukukan pada bab sebelumnya, maka kesimpulan yang dapat diambil dari penelitian ini adalah: Berdasarkan uji simultan (Uji-F) dapat diambil kesimpulan bahwa variabel independen secara simultan atau bersama-sama tidak berpengaruh terhadap pengungkapan sustainability report. Hasil pengujian secara parsial (Uji-t) menunjukkan bahwa masing- masing variabel independenya rata-rata tingkat kehadiran anggota dewan komisaris, dewan direksi dan komite audit dalam rapat tidak berpengaruh terhadap pengungkapan sustainability report. Hal ini disebabkan pada saat rapat, pembahasan lebih dititik beratkan pada kinerja perusahaan yang pengungkapannya bersifat wajib. Sehingga untuk pembahasan mengenai pengungkapan sustainability report tidak diutamakan.

Berdasarkan kesimpulan dalam penelitian, peneliti memberikan saran untuk perbaikan peneliti selanjutnya dengan mempertimbangkan hal-hal sebagai berikut: Menambahkan variabel lain dalam penelitian yang dipandang dapat mempengaruhi pengungkapan sustainability report, misalnya menggunakan prinsip atau mekanisme corporate governance lainnya. Peneliti selanjutnya dapat menambahkan periode pengambilan data, sehingga didapatkan hasilyang maksimal dan akurat dalam penelitian yang dilakukan. Membedakan perusahaan yang menjadi sampel berdasarkanjenis perusahaan, ukuran perusahaan dan karakteristik perusahaan sehingga data yang digunakan benar-benar dapat mencerminkan keadaan yang sebenarnya. 
Adhima, Mochammad Fauzan.2012. "Pengaruh Pengungkapan Sustainability Report terhadap Profitabilitas Perusahaan Studi Kasus pada Perusahaan Manufaktur yang Terdaftar dalam Bursa Efek Indonesia”. Jurnal Imiah Mahasiswa FEB. Universitas Brawijaya. Malang.

Keputusan Ketua Bapepam Nomor 38/PM/1996 tanggal 17 Januari 1996 mengenai laporan tahunan.

Fitri, G. N., \& B. Subroto. 2013. "Pengaruh Good Corporate Governance Terhadap Pengungkapan Corporate Social Responsibility Pada Perusahaan Yang Terdaftar di Bursa Efek Indonesia”. Jurnal Ilmiah Mahasiswa FEB UB 1 (2):116.

Ghozali, Imam. 2011. Aplikasi Analisis Multivariate Dengan Program IBM SPSS 19. Semarang: Badan Penerbit Universitas Diponegoro.

Nugroho, M. Firmansyah Fuad Aji. (2011). "Analisis Hubungan Antara Pengungkapan $C S R$ dan Karakteristik Tata Kelola Perusahaan Pada Perusahaan Manufaktur di Indonesia”. Skripsi. Undip.

Nurkhin, Ahmad. 2009. "Corporate Governance dan Profitabilitas; Pengaruhnya terhadap Pengungkapan Tanggung Jawab Sosial Perusahaan (Studi Empiris pada Perusahaan yang Tercatat diBursa Efek Indonesia)". Universitas Diponegoro. Semarang.

Pratiwi, NovitaIndra. 2013. "Analisis Pengaruh Corporate Governance Terhadap Sustainability Reporting Pada Perusahaan Yang Tergabung Di ISRA". Skripsi: Universitas Muhammadiyah Malang. Malang.

Rachmandy, Galih. 2012. "Analisa Penerapan PrinsipGood Corporate Governance (GCG) pada PT Bank Tabungan Negara (Persero) Tbk”.Universitas Brawijaya. Malang.

Ratnasari, Yunita. 2011. Pengaruh Corporate Governance Terhadap Luas Pengungkapan Tanggung Jawab Sosial Perusahaan Di Dalam Sustainability Report. Universitas Diponegoro. Semarang.

Reni, Fr. \& Retno Anggraini., 2006. Pengungkapan Informasi Sosial dan FaktorFaktor yang Mempengaruhi Pengungkapan Informasi Sosial dalam Laporan Keuangan Tahunan (Studi Empiris pada Perusahaan-Perusahaan yang terdaftar Bursa Efek Jakarta). Simposium Nasional Akuntansi 9. Universitas Sanata Dharma Yogya.

Rosadi, Jabal Jauhar. 2011. "Analisis Kinerja Keuangan Sebelum Dan Sesudah Penerapan GCG (Good Corporate Governance) (Studi Empiris Pada Perusahaan Publik Yang Disurvei IICG Indonesia Institute For Corporate Governance)".Universitas Muhammadiyah Malang. Malang.

Suryono, Haridan Prastiwi, Andri. 2011. "Pengaruh Karakteristik Perusahaan Dan Corporate Governance (CG) Terhadap Praktik Pengungkapan Sustainability Report (SR) (Studi Pada Perusahaan-perusahaan yang Listed (Go-Public) di Bursa Efek Indonesia (BEI) Periode 2007-2009)". Simposium Nasional Akuntansi XIV.

Sutedi, Adrian. 2012. Good Corporate Governance. Jakarta: Sinar Grafika.

Thomsett, Rob. 2006. Radical Project Management "Manajemen Proyek Radikal". Jakarta: Erlangga.

Republik Indonesia. 2007. UU No.23 tahun 2007 tentang pengelolaan lingkungan hidup

Republik Indonesia. 2007. UU No.40 tahun 2007 tentang Perseroan Terbatas.

www.jatam.org,2013 
Pengaruh

Corporate

Governance...

720
Widianto, Hari Suryono, 2011. "Pengaruh Profitabilitas, Likuiditas, Leverage, Aktivitas, Ukuran Perusahaan, dan Corporate Governance Terhadap Praktik PengungkapanSustainabilityReport(StudiPadaPerusahaan- Perusahaan Yang Listed (Go-Public) di Bursa Efek Indonesia (BEI) Periode 2007-2009)". Universitas Diponegoro. Semarang 